\title{
Supernumerary Nostril: A Case Report and Review
}

\author{
Fosa Nasal Supernumeraria: Reporte de un Caso y Revisión
}

*Sushil Kumar Kashyap \& **Mohd Azim Khan

\begin{abstract}
KASHYAP, S. K. \& KHAN, M. A. Supernumerary nostril: A case report and review. Int. J. Morphol., 27(1):39-41, 2009.
SUMMARY: Supernumerary nostril is a very rare congenital anomaly, which includes additional nostril with or without accessory cartilage. In the present case of the left supernumerary nostril, a small cavity of around $3 \mathrm{~mm}$ diameter and accessory lower lateral cartilage were present. The cavity was lined with mucous membrane and filled with mucoid discharge .Nasal endoscopy of accessory nasal cavity revealed that it was small as compared to normal nasal cavity and did not communicate with the ipsilateral nasal cavity. The diameter of the normal anterior nasal opening was less on left side as compared to right side. Unilateral supernumerary nostril may occur because of the fissuring of the lateral nasal process during fetal growth.
\end{abstract}

KEY WORDS: Supernumerary nostril; Congenital anomaly; Fissuring of nasal process.

\section{INTRODUCTION}

Supernumerary nostril is a very rare type of congenital anomaly which includes additional nostril with or without accessory cartilage. It can be unilateral or bilateral. Lindsey (1906) reported the first case of bilateral supernumerary nostril, in that case external openings of supernumerary nostrils were situated above the normal nostril and the accessory nasal cavities communicated with the ipsilateral nasal cavities. Tawse (1920) reported a patient with a unilateral supernumerary nostril that communicated with the nasal cavity. Reddy \& Rao (1987) reported a case of a third nostril that was situated below the left nostril. Sinha et al. (2005) described a case of supernumerary nostril with micro cornea and congenital cataract.

In the present case report, we are describing a case of unilateral supernumerary nostril and also discuss the hypothesis that has been proposed to explain supernumerary nostrils.

\section{CASE REPORT}

A 6 - months old male baby was brought to ENT Department for evaluation of an opening above the left nostril that had been present since birth. There was history of persistent whitish fluid discharge from the opening. Antenatal history was uneventful and the child's birth was normal. The child had reached normal milestones of motor and intellectual development. No family history of such an anomaly was reported. On physical examination there was a small cavity of around $3 \mathrm{~mm}$ diameter found above the left nostril. On palpation, the extra lower lateral cartilage was present, forming ala of supernumerary nostril (Fig.1). The cavity was lined with mucous membrane and filled with mucoid discharge. The diameter of the normal anterior nasal opening was less on left side as compared to right side (Fig. 2). The nasal endoscopy of accessory nasal cavity revealed that it was small as compared to normal nasal cavity and did not communicate with the ipsilateral nasal cavity.

\section{DISCUSSION}

The literature of embryology describes that the mesenchyme covering the caudal surface of the forebrain proliferates with surface ectoderm to form frontonasal process and the two ectodermal thickenings (nasal placodes) arise on each side of the depedent part of the frontonasal

\footnotetext{
* Asst. Professor, Dept. Of E.N.T., MLB Medical College, Jhansi, India.

** Asst. Professor, Dept. of Anatomy, MLB Medical College, Jhansi, India.
} 


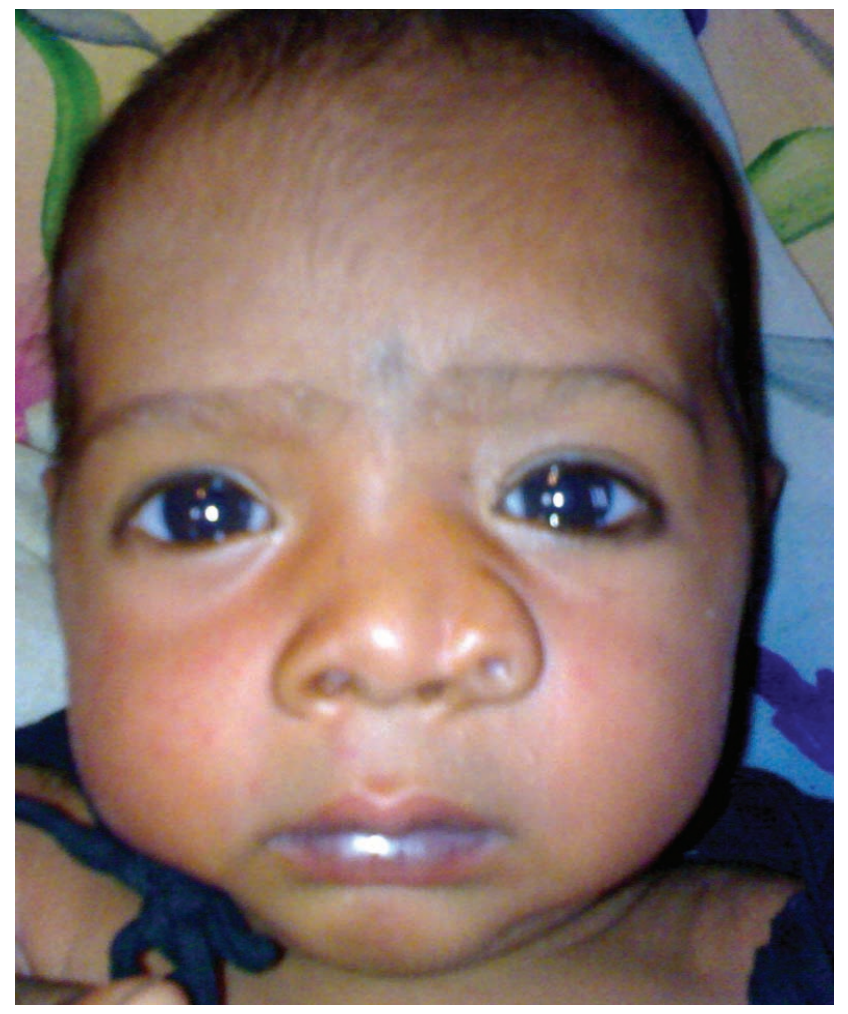

Fig. 1. Photograph showing supernumerary nostril on left side with accessory alar cartilage

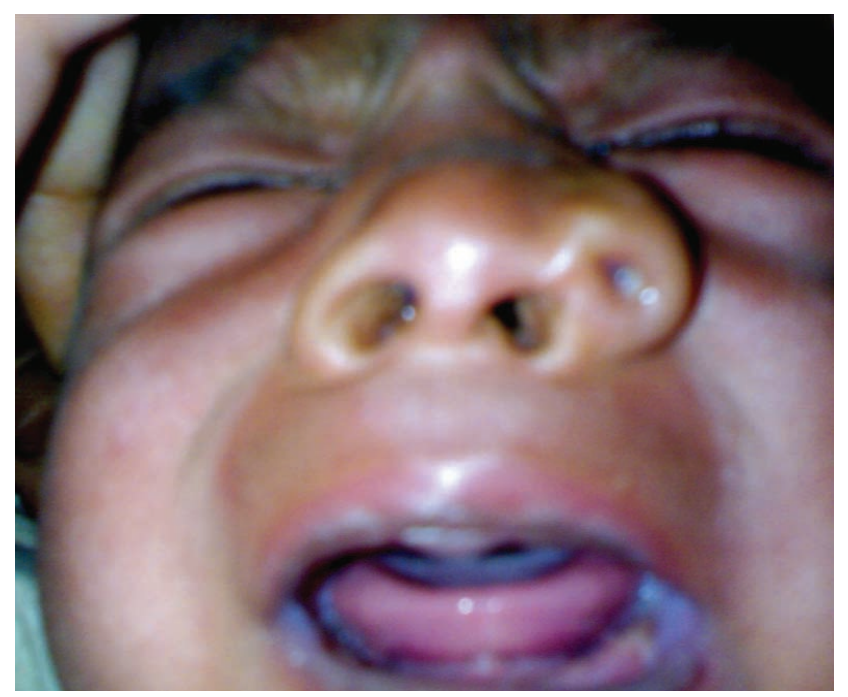

Fig. 2. Photograph showing narrowing of left normal nostril and supernumerary nostril.

process (Johnson, 1989). Subsequently the depression develops in the surrounding mesenchyme on each side of the two nasal placodes to form the olfactory pits. These olfactory pits dividing the frontonasal process into a medial and two lateral processes to form the primitive nasal cavity, while lateral nasal process forms the alae of the nose (Brown
\& Brown, 1998). The supernumerary nostril is result of the abnormal developmental process in the formation of the nose and nasal cavity, which may be in the form of total duplication of the nasal placode or the fissuring of the lateral nasal process. The supernumerary nostril is exceedingly rare congenital anomaly of unclear etiology. Erich (1962) reported a case of double nose and supported Lindsey's theory (1906) of the dichotomy by atavism or parallel evolution. Onizuka \& Tai (1972) reported the case of a single accessory nostril that had developed above the nasal ala. The random fissuring of the lateral nasal process during fetal development will yield unilateral and asymmetric deformity (Nakamura \& Onizuka, 1987; Chen \& Yeong, 1992; Williams et al., 1998). Hallak et al. (2001) reported a case of supernumerary nostril with blind nasal cavity in a normally developed nose. Zbar et al. (2003) reported a case of - supernumerary nostril with extra lower lateral cartilage and also supported the theory embryological fissuring of the lateral nasal process. Sinha et al. reported a case of supernumerary nostril with microcornea and congenital cataract and speculated that anomaly in development of the nasal placodes is the cause.

The presence of alar cartilage in present case report describes the embryological fissuring of the lateral nasal process and formation of supernumerary nostril. This theory has been supported by various authors in past.

KASHYAP, S. K. \& KHAN, M. A. Fosa nasal supernumeraria: Reporte de un caso clínico y revisión. Int. J. Morphol., 27(1):39-41, 2009.

RESUMEN: Fosa nasal supernumeraria es una anomalía congénita muy poco frecuente, que incluye una nueva fosa nasal con o sin cartílago accesorio. En el presente caso de fosa nasal supernumeraria izquierda estaban presentes, una pequeña cavidad de unos $3 \mathrm{~mm}$ de diámetro y cartílago lateral accesorio inferior. La cavidad estaba revestida con membranas mucosas y llena con descarga mucoide. La endoscopía nasal de la cavidad nasal accesoria reveló que ésta era pequeña en comparación con la cavidad nasal normal y que no se comunicaba con la cavidad nasal ipsilateral. El diámetro normal de la apertura nasal anterior fue menor en el lado izquierdo en comparación con el lado derecho. La fosa nasal unilateral supernumeraria puede ocurrir a causa de las fisuras del proceso lateral nasal durante el crecimiento fetal.

PALABRAS CLAVE: Fosa nasal supernumeraria; Anomalía congénita; Fisura del proceso nasal. 


\section{REFERENCES}

Brown, K. \& Brown, O. E. Congenital malformation of the nose. Cummings, C. W. Eds. Otolaryngology-Head and neck surgery. $3^{\text {rd }}$ Ed. Mosby, St. Louis, 1998. pp.92-103.

Chen, M. T. \& Yeong, E. K. Supernumerary nostrils. Br. J. Plast. Surg., 45:557-8,1992.

Erich, J. B. Nasal duplication: Report of case of patient with two noses. Plast. Reconst. Surg., 29:159-66, 1962.

Hallak, A.; Jamjoom, H. \& Hosseinzadeh, T. Supernumerary nostril: a case report and review. Aesthetic. Plast. Surg., 25:241-3, 2001.

Johnson, K. E. Development of the face, oral cavity, and pharyngeal pouches. Johnson, K. E. (Editor). Human developmental anatomy. John Wiley \& Sons, New York, 1989. pp.303-20.

Lindsey, B. A nose with supernumerary nostrils. Trans. Pathol. Soc. Lond., 57:329-36, 1906.

Nakamura, K. \& Onizuka, T. A case of supernumerary nostril. Plast. Reconst. Surg., 80:436-41, 1987.

Onizuka, K. \& Tai, Y. Supernumerary nostril: A case report. Plast. Reconst. Surg., 50:403-5, 1972.

Reddy, K. A. \& Rao, A. K. Tripple nostrils: A case roport and review. Br. J. Plast. Surg., 40:651-2, 1987.

Sinha, R.; Das, S.; Sikder, B.; Ray, S. \& Bit, U. K. Supernumerary nostril with congenital cataract. Ear Nose Throat J., 84:716-9, 2005.

Tawse, H. B. Supernumerary nostril and cavity. Proc. R. Soc. London., 13:28,1920.

Williams, A.; Pizzuto, M.; Brodsky, L. \& Perry, R. Supernumerary nostril: a rare congenital deformity. Int. J. Pedia. Otorhinolaryngol., 44:161-7, 1998.

Zbar, R.I.; Rai, S. M. \& Ghimire, P. Repair of congenital nasal anomalies involving redundancy of structures. Cleft Palate Craniofac. J., 40(2):214-7, 2003.
Correspondence to:

Mohd Azim Khan

Asst. Professor

Department of Anatomy

Type IV/ 3, MLB Medical College

Jhansi

INDIA

Phone Nº 09936704832

Email: drazim@rediffmail.com

Received: 01-02-2008

Accepted: 20-11-2008 
